\title{
REGENERATION IN THE ANTHROPOCENE: TRANSCENDING SUSTAINABILITY WITHIN
} CAPITALIST REALISM

\begin{abstract}
Björn Barutzki ${ }^{1}$
Abstract/Resumen

In recent years, a number of activists and scholars have moved away from the notion of simply trying to sustain ecological, social and economic spheres, but rather focus on co-evolution of socio-ecological systems in their attributions of resilience, change coping and forming mechanisms and design principles under the framework of regenerative development or regenerative design. Examining Daniel C. Wahls approach of Designing Regenerative Cultures and other thinkers of holistic socio-ecological design, this article tries to experiment with a possibly new progressive influx to re-orientate the sustainability debate from the need to the want - engaging on the simple mantra of transformational change happening by design or by disaster and making the conscious decision for design. Within the concept of Capitalist Realism coined by Mark Fisher, the narratives leading us towards disaster are examined and contrasted to storytelling approaches of life-sustaining and flourishing futures.
\end{abstract}

Keywords: regeneration; narratives; growth paradigm; futures storytelling; transformation; design

\section{LA REGENERACIÓN EN EL ANTROPOCENO: TRANSCENDIENDO LA SOSTENIBILIDAD EN EL REALISMO CAPITALISTA}

En los ultimos años, varios activistas y académicos se han alejado de la idea de simplemente tratar de mantener disciplinas ecológicas, sociales y económicas y centrarse más bien en la evolución conjunta de sistemas socio-ecológicos en sus atributos de resiliencia y formación de mecanismos de enfrentamiento y adaptación, y diseñar principios bajo el marco de los conceptos de desarollo regenerativo o diseño regenerativo. Examinando Designing Regenerative Cultures de Daniel C. Wahl y otros pensadores del diseño socio-ecológico, el artículo trata de experimentar con la posibilidad de un nuevo influjo progresivo para re-orientar el debate sobre la sustentabilidad del necesitar al querer, usando el mantra de cambio transformativo, pasando por desastre o por diseño y eligiendo diseño conscientemente. Dentro del concepto de realismo capitalista acuñado por Mark Fisher, las narrativas que nos conducen al desastre se examinan y contrastan con los enfoques de futuros sustentadores y florecientes.

Palabras claves: regeneración, narrativas, paradigma del crecimiento, relato del futuro, transformación;diseño

\footnotetext{
${ }^{1}$ Germany. E-mail: bbarutzki@ posteo.de
} 


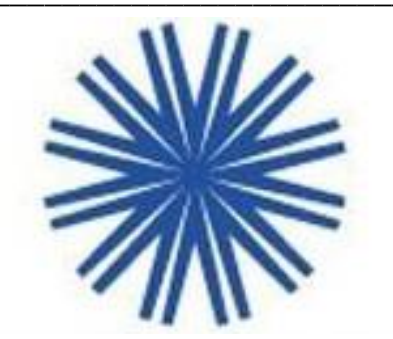

Climate change will transform global systems, creating new system rules, new stories of place and new potential.

Chrisna du Plessis (2011: 19)

Much in the same way the cynical (?!) yet devastating quote "It's easier to imagine the end of the world than the end of capitalism" associated with Frederic Jameson, Slavoj Žižek and the late Mark Fischer still sums up our collective disability to imagine other futures, the sustainability discourse is stuck in much of the same self-limiting dynamic: The whole notion of sustainable development suggests the image or fixed idea of knowing what it is we as a global collective whole want to sustain. The conservation of the status quo that the term yet indirectly implies - since it, as Blühdorn (2017) points out, doesn't map out possible ways of transcending liberal consumer capitalism - surely won't be the set of tools and imagery mechanisms we need to truly transform ourselves, our societies and our relationships to the environmental systems around and within us. Perhaps the dilemma of the sustainability discourse is blocking itself precisely here: "Sustainability is not enough; we need regenerative cultures." (Wahl, 2016: 43)

As the multiple converging crises we face are creating an accelerated climate of transformation, where change is no longer a possibility to entertain but an inevitable consequence of our collective actions, we are called to switch out the mindset that created these crises in the first place.

Daniel C. Wahl (2016: 35)

Much has been written on the natural, social, cultural and political change required to not just greenwash our modes of living. Nonetheless, the most widespread assumption still seems to be - both in popular culture and mainstream politics - that we can just keep on living the way we have in the last 50 years. But sustainably. Somehow. Even eco-technological aspirations summed up under the Green New Deal imagery with its key notion of decoupling economic growth from natural resource consumption rate, don't go the extra step to meet the problems the human family faces head-on (Paech, 2017, January 19; Blühdorn, 2009, October 30). Blühdorn (2017) speaks of the ,pervasive culture of denial' when adressing the observation that most concepts concerning sustainable development, ecological modernization and ,narratives of hope' presented by ecological sociologists:

"leave the core principles of liberal consumer capitalism untouched“ (p. 2), thus helping ,to provide cover under which the socially and ecologically destructive order could continue to flourish and deplete the 
cultural resources which are essential to even imagine, let alone implement, any alternative to the status quo." (p. 3)

As Alberto Escobar (2015) points out in Thinking-feeling with the Earth, ,we are facing modern problems for which there are no longer modern solutions" (p. 15; emphasis in the original), since ,the understanding of the world is much broader than the western understanding of the world." (p. 16; emphasis in the original) Prolonging the present is about as much as we seem to be able to come up with when thinking the future. Unable to manage, reorientate and adapt to and with the change already happening, we not only need to find ways to deal with the geophysical implications of a changing climate but also - if not even more - revisit, undo and rewrite the assumptions we have built into stories driving our political institutions, systems and cultural beliefs.

If we could feel what we are doing to the earth, we would immediately stop. Associated with Terence McKenna

Feeling the future, on the other hand, requires a very different approach. The stories we tell each other in order to give meaning and orientation points are not merely cultural artefacts, bits of history with regional differences. They are in fact the way we structure our perception of what we believe to be the reality. Bruno Latour would argue the great narrative of modernity is that of the believed separation between nature and culture - between subjective human actors and objective non-human artefacts (Latour, 1993). In much the same way, Daniel C. Wahl speaks of the narrative of separation when addressing the dire need to re-construct our collective imaginary towards the narrative of interbeing: Deconstructing the separation-belief is essential if we truly want to recognize climate change being culture change and vice versa. Climate is as much culture, as weather is locally focused patterns of climate dynamics; and culture in the Anthropocene defines what climate means, not just is.

As scholars such as Jason W. Moore $(2017,2018)$ have argued, the debate around the Anthropocene - the geological impact of , human activity' having become the prime geophysical force of the planet - leads to similiar obscuring dynamics of global power-relations, re-inforcing the very foundation of seperation, that lead to over-exploitation of the planets human and non-human resources and beings in the first place - the supposed seperation between human kind and nature. For this reason, mainstream discourse is able to 
speak of the environmental crisis, the crisis of democracy and so on, instead of figuring these as systemic crises - as crises of perception. (Capra, 1990)

But why is re-framing the space in which we dismantle long hold belief-systems, navigate the unknown terrain of a warming atmosphere and its uncertain feedback loop dynamics, and establish a holistic view of the way forward so important? Simply put because our minds run on a mechanism described as cognitive dissonance. The stories we tell each other to make sense of the world - narratives, memes, models, concepts and so on - filter our experiences, expectations and worldviews into our selfidentification with the cultural system(s) around us. Cognitive dissonance thus is our brains memeorganisation mechanism to let us act in certain ways despite these actions contradicting i.e. our feelings, empirical evidence and scientific consensus: Cognitive dissonance lets us consume the version of reality we conceive of to be true. The manifestation of ideology - the rule of an idea so to speak - into the biophysical realm functions precisely in this way, since it overrides the real to make sense of the environment it finds itself in:

"The beliefs we hold, what we value, where we spend the money we have, and most of all by the way we behave towards ourselves, our human community and towards the rest of the community of life - all of this contributes to the emergence of the cultures we live in. In turn, these cultures condition the way we see the world and what we focus on, the stories we tell about ourselves and the world." (Wahl, 2018, September 01)

The late Mark Fischer, in his iconic essay Capitalist Realism, poetically peeled off the layers of psychological mechanisms of (un)conscious self-deceit underlying the catastrophic realization of the Global Norths Western-industrialised collective's incapacity to transcend neoliberal fantasies of noalternativism: "Capitalist ideology in general (...) consists precisely in the overvaluing of belief - in the sense of inner subjective attitude - at the expense of the beliefs we exhibit and externalize in our behaviour." (Fischer, 2009: 13)

The neoliberal globalized capitalistic economic system builds upon the collective belief of its absolution, the notion of the growth paradigm it feeds upon being imperative and the deadly incorporation of critique into its subsystems. It is through this characteristic that the notion of Green Growth is even possible to be brought into discursive practice. 
"(...) the fantasy structure on which capitalist realism depends: a presupposition that resources are infinite, that the earth itself is merely a husk which capital can at a certain point slough off like a used skin, and that any problem can be solved by the market." (Fischer, 2009: 18)

Fischer pointedly works out the interdependence between capitalism and ecological disaster, when noting that "capital's 'need of a constantly expanding market', its 'growth fetish', mean that capitalism is by its very nature opposed to any notion of sustainability." (Fischer, 2009: pp. 18-19) It is this growth fetish and its effects that scholars around the world are trying to conceptualize in order to find alternatives that evolve around the narratives of Degrowth, Buen Vivir and other pluriverse epistemologies. (Giacomo et. al., 2015; Kothari et. al. forthcoming 2018)

It matters which stories tell stories, which concepts think concepts.

Donna Haraway (2015: 160)

Of course, there is no alternative to growth, to extreme resource extraction, to market-demanded overproduction and -consumption, when our mental storyboards don't allow other viewpoints, other entrance ways and visions of pasts, presents and futures to express themselves. If anything, there is no alternative to changing the way we relate to the world. But why change the play screen, when you can just switch out the lightings? Run the theatre the same way, but now with green energy. In much the same way, it is this cognitive hypocrisy that the term of sustainable development implies. Development in the current narrative of growth is by definition a quantitative category. Quantity maximisation within finite space can only even remotely sound feasible when sugarcoated with technological progress: The promise of a future where today's problems can be dealt with - the psycho-social foundation of pathological procrastination. Yet as Sommer and Welzer (2016) analyse, Western industrialized capitalism isn't just ideologically unsustainable, but rather structurally not designed to be sustainable: It is degenerative by default since it ultimately destroys the basis it feeds upon - it consumes itself. Sustainability advances within the growth regime, therefore, can not but scratch the surface of the problem(s). Without changing the mental infrastructures (Welzer, 2011) on which societies and their underlying cultural assumptions run upon, adjustments in biophysical infrastructures are unable to truly change towards solutions for the crises at hand, let alone transform the cultural adaptation capacity of the socio-ecological system, because the perception of these crises does not. Wahl sums it up when saying that 
"[i]t is time to step back from our cultural predisposition to want solutions and answers as quickly as possible. Do symptomatic quick fix solutions - rather than systemic transformation - actually serve the necessary culture change? Or, are they merely premature responses to mistaken problem statements created within an outdated way of thinking, based on a cultural narrative that no longer serves humanity?" (Wahl, 2016, April 27)

Why is addressing our mental infrastructures so difficult? What exactly is it that is keeping us as human animals on this planet along with millions of other sentient beings from existing in a different mode of living? Latour, who in recent years has namely contributed to the (re-) politicization of the Anthropocene debate among the humanities, sees "(...) the ecological crisis of the Anthropocene as a fundamental crisis of modernity - a modernity built on abstract assumptions and detached from its material constraints." (Latour, 2018) Leaving the interdisciplinary debate of what exactly constitutes the modern aside, the notion of separation is inherently and crucially obvious: What does not belong to my realm of responsibility, is out of my zone of concern. The irony of globalized capitalism itself alas seems to be becoming clearer and clearer, since from a cultural evolutionary point of perspective "modernity turns out to be just as unable in responding to eminent change" (Latour, 2018) as closed off, local societies. Neither one seems to be able to connect the dots between their glocal - the intertwining of global and local dynamic patterns - position in time and space, nor the evolutionary necessity of adapting to changes in their socioecological systems. The real dilemma of the Anthropocene that we are witnessing now is the neoliberal politically re-enforced, corporate-sanctioned hybris of (un-)knowable figures and facts that keep us from the most urgent of questions: How to find "(...) another way to live on this Earth." (Latour, 2018)

Wahl suggests overcoming the sustainability dilemma by focusing on what comes after we have bridged the gap between now and then. Hence, the question - what is it we want to sustain? What figures and characters of our old narratives do we keep and what do we need to replace? Firstly, "[t]he separation of nature and culture is a figment of our imagination, just like the separation between mind and body, consciousness and matter, self and world, theory and praxis. From a truly participatory understanding of reality everything is natural." (Wahl, 2018, September 16)

As described above, the cultural matrix of Western (post)modern societies has developed in the last 250 years on the Cartesian-rational of humanity being separated from the rest of the web of life in a Newtonian- 
mechanistic logic (Cole, 2012). The "logic" of unlimited growth on a finite planet can only be proposed when this separation is assumed. The consequences of this short-sighted worldview are visible globally and increasingly threatening the stabilizing factors of the Holocene upon which homo sapiens has been able to evolve civilization. The return to nature-meme of many green activists and sustainability advocates is thus also at least irritating. What nature is there supposed to be to which one could return? And from where? Culture? Society? Civilization? It is this "'alteration of the relation to the world'" (Latour, 2017: 10), this definitive discrepancy between our dearly - clearly? - needed distinguishability between nature out there and culture inside here that defines the territoriality of the space capitalism, or better the unnameable ideology of capitalist realism, believes to be able to function in. The anthropogenic of the Anthropocene - leaving aside the legitimate debate between offender and victim perspectives in suggestions such as the Capitalocene (Haraway, 2015; Moore, 2017, 2018) - seems to reside right here:

What happens when the out there and the inside here become the out here and the inside there? What's left of the human being when it has no outer something to define itself upon; the inside out of our cultural logic becomes a self-destructive - self-destructing! - item on the menu? Perhaps looking for answers to this question is exactly what we need. Wahl amongst other thinkers links this identity-crisis with the ecocide happening underneath our noses. Since our cultural narratives of growth, accumulation and projecting the future into the future have failed us, what is it we put in its place - how do we choose to design the human condition so that there is an environmental foundation with the capacity to support it? How do we solve the dilemma of living "in a 'permanent present' where a discounting of the past parallels inattention to the future" (Lever-Tracy, 2008: 452): "Is there life after information/consumer/post whatever society?" (Lever-Tracy, 2008: 454) In this context, Pinchbeck puts forth his analysis of a planetary regenerative society under the mantra of How Soon Is Now?; the future already being here, just not evenly distributed.

Regeneration has to do with the rebirth of life itself, thus with hope for the future. John T. Lyle (1994:11)

Wahl contradicts the narrative of separation outlined above as the meaning-making-mechanisms of degenerative systems embodied in the manifestations of Capitalist Realism with the narrative of interbeing. The anthropocentric conditioning implied in the narrative of separation has at last lead to the "(...) ecological, environmental, social and economic crises we are facing", which "are not separate but 
interconnected expressions of one single crisis: a crisis of perception." (Wahl, 2016: 83) Spreading the story is thus not just an educatory necessity, but an essential imperative of a regenerative shift in consciousness or as Göpel (2016) frames it - the Great Mindshift:

"Spreading the story of why we care about life and the health of the whole and sharing the narrative of interbeing is culturally creative meta-design. By sharing the new and ancient story of interbeing we facilitate the emergence of diverse regenerative cultures scale-linked by empathy and cooperation." (Wahl, 2017, February 26; emphasis the original)

The regenerative meta-design Wahl speaks of first and foremost distinguishes itself from the status quo and its conspicuous lack of viable future visions in the primal aspect of degenerative concepts - that of unlimited growth within finite space. In similar terms, Raworth (2017) uses the slogan of Create to Regenerate when designing a new economic model that promotes social wellbeing for all while living and thus managing economics within planetary boundaries. Quantitative growth measured in GDP and other financial numerics doesn't reflect - and thus integrates - its metabolism flows into its calculations. It assumes technological innovation - where exponential growth rates are theoretically feasible - to fix the gap between inclining production and consumption patterns and declining resources, thus assuming exponential growth for the globalised economy as a possible pathway. Needless to say, nothing in nature grows exponentially in the sense of unlimitness - its simply not the way growth patterns function in cyclical biological systems that evolve complexity. A holistic perspective on growth within living systems hence needs to take the "dynamic balance between growth, decline, and recycling" (Capra \& Henderson, 2013: 9) into consideration, which leads to cyclical dynamics that are able to not just sustain the system but evolve it dimensionally. For this reason, Capra \& Henderson (2013) distinguish between economic quantitive growth and ecological qualitative growth, with the latter describing sigmoidal growth patterns. The growth curve of sigmoidal - or s-curved - development signifies a sustainable balance between inclination and declination (Fullerton, 2016, July 06), indicating development dynamics being "processes and patterns of relationships" (Capra \& Henderson, 2013: 7), which need "to be mapped rather than measured." (Wahl, 2016: 225).

Nature does more than sustain herself; she flourishes and thrives. Daniel Pinchbeck $(2017,14)$ 
Mapping the interdependencies between system attributes and causal chains could help us analyse and distribute information back into the knowledge producing factories of institutionalised politics, science, and civil society which could then constantly reevaluate the qualitative growth necessities in comparison with the quantitative growth necessities of a given locality. Qualitative growth could thus be used to redesign the way we perceive the metabolism between societies and their living system-environments. As mentioned before, sustainability cannot simply be about sustaining the status quo. Mainly, it must also function as a repairing tool for societal and ecological resilience and overall systemic health - a regenerating system. In correspondence to the regenerative paradigm shift outlined above, du Plessis (2012) describes sustainability "not as an aggregate of social-economic-technological solutions, but rather an emergent property arising from the interactions of all these systems." (p. 11)

"The regenerative potential in the social-ecological system is revealed through a set of processes that engage with and integrate various narratives at different levels and scales of the system under consideration into a meta-narrative that is used to extract a vision, purpose and principles to guide the development and design process." (du Plessis, 2012: 18).

So how do we web these insights into a narrative storyline that encourages people to shift their consciousness and subsequently their behavior? Perhaps a central figure could be that of the healing properties of real-world systems, in the sense that they incorporate change in a cyclical adaptation mechanism. This would imply disruptive and transformative change as we are witnessing climate change to be, being incorporated into the socio-cultural fabric. Incorporating change as the key driver of evolutionary adaptation with the focus of healing then would reinforce the meme of individual, collective and ,systemic health and resilience at different scales, from local, to regional and global“" (Wahl, 2016: 43 ) as the main factors of sustainability and regeneration. The Capital Institute speaks of Regenerative Capitalism that induced with the story of systems being ,healthy, regenerative energy flow networks“ (Fullerton, 2015: 106; emphasis in the original) could spark a shift in perception from reductionist to systemic point of views, since it picks people up at a certain collective point of understanding and leads it to a new outlook on not just economics, but rather life in general. Within the same framing, Capra \& Luisi (2014) speak of "the fundamental change of metaphors from seeing the world as a machine to understanding it as a network." (452) From decades of studying "complex biological and social systems", Capra \& Luisi (2014) conclude that "meaningful disturbances can trigger multiple feedback processes that may rapidly lead to the emergence of a new order." (452). 
How can we make Qualitative-Growth-Futures feasible to the general public, while taking into consideration different development dynamics in the Global North and Global South? Projected unto the macro scale of global civilization, how could a sustainable - because regenerative - society look like without falling into the trap of top-down hierachies and not just maintaining but reinforcing regional diversity? What would its cultural codes be, which horizon could it offer its members? How can it foster hope for the present, rather than dread for the future? This is where the real work needs to be done mediating the search for new imaginaries revolving around ecocentric worldviews instead of anthropocentric - or egocentric - narratives, that build upon the notion of sustainability as a life reenforcing concept:

"This leads to a view of sustainability that moves beyond a simplistic model achieving balance between economy, society and environment to a model based on resilience and adaptive capacity and a coevolutionary partnership between humans and the natural environment of which they form part that is aimed at the regeneration of social-ecological systems." (du Plessis \& Cole, 2011: 446-447)

\section{Bibliographic references}

Blühdorn, I. (2009, October 30) Locked into the politics of unsustainability - Eurozine. Retrieved from https://www.eurozine.com/locked-into-the-politics-of-unsustainability/

Blühdorn, I: (2017): Post-capitalism, post-growth, post-consumerism? Eco-political hopes beyond sustainability. Global Discourse, 7:1, 42-61, DOI: 10.1080/23269995.2017.1300415

Capra, F. (1990): The Crisis of Perception. The Futurist, 24:1.

Capra, F. \& Henderson, H. (2013). Qualitative Growth. A conceptual framework for finding solutions to our current crisis that are economically sound, ecologically sustainable, and socially just. UK: ICAEW. Retrieved from https://www.icaew.com/-/media/corporate/files/technical/sustainability/qualitativegrowth.ashx?la=en

Capra, F. \& Luisi, P.L. (2014). The Systems View of Life: A Unifying Vision. Cambridge, UK: Cambridge University Press.

Cole, R. J. (2012). Regenerative design and development: current theory and practice. Building Research \& Information, 40(1), 1-6. DOI: DOI: 10.1080/09613218.2012.617516

D’Alisa, G.; Demaria, F. \& Kallis, G. (2015). Degrowth - A Vocabulary For A New Era. UK: Routledge.

du Plessis, C. \& Cole, R.J. (2011). Motivating change: shifting the paradigm. Building Research \& Information, 39(5), 436-449. DOI: 10.1080/09613218.2011.582697 
du Plessis, C. (2012). Towards a regenerative paradigm for the built environment. Building Research \& Information, 40(1), 7-22. DOI: 10.1080/09613218.2012.628548

Escobar, A. (2015): Thinking-feeling with the Earth: Territorial Struggles and the Ontological Dimension of the Epistemologies of the South. Madrid: Revista de Antropología Iberoamericana, 11:1, 11-32. DOI: 10.11156/aibr.110102e

Fischer, Mark (2009). Capitalist Realism: Is there no alternative? UK: Zero Books.

Fullerton, J. (2015). Regenerative Capitalism: How Universal Principles And Patterns Will Shape Our New Economy. Greenwich, USA: The Capital Institute.

Fullerton, J. (2016, July 06). Realities of Shifting to a Sustainable Economy. Retrieved September 27, 2018, from https://www.ecowatch.com/realities-of-shifting-to-a-sustainable-economy-1881890107.html

Göpel, M. (2016). The Great Mindshift. How a New Economic Paradigm and Sustainability Transformations go Hand in Hand. Switzerland: Springer International Publishing.

Haraway, D. (2015). Anthropocene, Capitalocene, Plantationocene, Chthulucene: Making Kin. Environmental Humanities, Vol. 6, 159-165.

Kothari, A.; Salleh, A.; Escobar, A.; Demaria, F. \& Acosta, A. (Eds.). (forthcoming, 2018). Pluriverse: A Post-Devolopment Dictionary. Delhi, India: Authors Up Front.

Latour, B. (1993). We have never been modern. Cambridge, USA: Harvard University Press.

Latour, B. (2017). Facing Gaia: Eight Lectures on the New Climatic Regime. Boston, USA: Polity.

Latour, B. (2018). Anthropocene Lecture: HKW Berlin 4th of May 2018. Retrieved from http://www.bruno-latour.fr/node/770

Lever-Tracy, C. (2008). Global Warming and Sociology. Current Sociology, (56), 445-466.

Lyle, J. T. (1994). Regenerative Design For Sustainable Development. New York, USA: John Wiley \& Sons, Inc.

Moore, J. W. (2017) The Capitalocene, Part I: on the nature and origins of our ecological crisis, The Journal of Peasant Studies, 44:3, 594-630, DOI: 10.1080/03066150.2016.1235036

Moore, J. W. (2018). The Capitalocene Part II: accumulation by appropriation and the centrality of unpaid work/energy. The Journal of Peasant Studies, 45:2, 237-279. DOI: $10.1080 / 03066150.2016 .1272587$

Paech, N. (2017, January 19). The Destructive Dream of Progress. Retrieved from https://www.degrowth.info/en/2017/01/the-destructive-dream-of-progress/ 
Pinchbeck, D. (2017). How Soon Is Now? USA: Watkins.

Pinchbeck, D. (2017). Author of "How Soon Is Now?" [Interview by K. Calian]. The Regeneration, (1), 13-25.

Raworth, K. (2017). Doughnut Economics: Seven Ways to Think Like a 21st-Century Economist. UK: Random House.

Sommer, B. \& Welzer, H. (2016). Transformationsdesign: Wege in eine zukunftsfähige Moderne. Munich, Germany: Oekom.

Wahl, D. C. (2016). Designing Regenerative Cultures. Charmouth, UK: Triarchy Press Ltd.

Wahl, D. C. (2016, April 27). Join the Re-Generation! Designing Regenerative Cultures. Retrieved from https://medium.com/insurge-intelligence/join-the-re-generation-designing-regenerative-cultures$77 \mathrm{f} 7868 \mathrm{c} 63 \mathrm{~cd}$

Wahl, D. C. (2017, February 26). Collaboration and empathy as evolutionary success stories. Retrieved from https://medium.com/@designforsustainability/collaboration-and-empathy-as-evolutionary-successstories-4e $7 \mathrm{cfd} 12 \mathrm{e} 5 \mathrm{c} 8$

Wahl, D. C. (2018, September 01). Is it possible to design culture? - Hacker Noon. Retrieved from https://hackernoon.com/is-it-possible-to-design-culture-eb4de7251533

Wahl, D. C. (2018, September 16). Why Do We Need to Design as Life? - NYC Design - Medium. Retrieved from https://medium.com/@designforsustainability/why-do-we-need-to-design-as-life$1144 \mathrm{e} 06 \mathrm{f} 14 \mathrm{~b} 5$

Welzer, H. (2011). Mentale Infrastrukturen. Wie das Wachstum in die Welt und in die Seelen kam. Berlin, Germany: Schriftenreihe Ökologie Band 14, Heinrich-Böll-Stiftung. 